\title{
EVALUATION OF EROSION-CORROSION BY JET IMPINGEMENT TESTS ON A CR/CRN BILAYER COATING DEPOSITED BY CATHODIC ARC*
}

\author{
Johanna Alegría-Ortega ${ }^{1}$ \\ Luz Marina Ocampo-Carmona ${ }^{2}$ \\ Fernando Rodríguez ${ }^{3}$ \\ Ignacio Cortes ${ }^{4}$ \\ Elena Forlerer ${ }^{5}$
}

\begin{abstract}
$\mathrm{Cr} / \mathrm{CrN}$ bilayer coating was deposited on AISI $440 \mathrm{C}$ by Cathodic Arc. The composition and structure of the $\mathrm{Cr} / \mathrm{CrN}$ coating were investigated by scanning Electron Microscope, X-Ray Diffraction and X-ray Photoelectron Spectroscopy. The results show that crystal structure obtained was CrN phase with preferred [220] orientation. The hardness and adhesion of coating also were studied. The evaluation of erosion-corrosion (EC) on $440 \mathrm{C}$ bare and coated with $\mathrm{Cr} / \mathrm{CrN}$ was performed by carrying out wear tests using a slurry jet with impingement angle $90^{\circ}$ at 4 and $8 \mathrm{~m} / \mathrm{s}$. Corrosion, erosion and synergism wear rate were evaluated following the procedure described in ASTM G-119-09. This study presents that the synergism wear rate exceeds $40 \%$ of the total mass loss for coating and $60 \%$ of mass loss for the $440 \mathrm{C}$, being the most aggressive wear component. The increase in impact velocity generated a rise in mass loss for both $440 \mathrm{C}$ bare and coated. The $\mathrm{Cr} / \mathrm{CrN}$ coating offers better corrosion and erosion-corrosion resistance under all the tested conditions.
\end{abstract}

Keywords: Multilayer coating; Staintess steel; Cathodic arc; erosion-corrosion.

1 M.Sc. Eng., Grupo de Ciencia y Tecnología de Materiales, Universidad Nacional de Colombia, Medellín, Colombia; jaalegri@unal.edu.co.

2 Ph.D. Eng., Grupo de Ciencia y Tecnología de Materiales, Universidad Nacional de Colombia, Medellín, Colombia.

3 Eng., División Recubrimientos y Tribología, Gerencia de Materiales, GAEN, Comisión Nacional de Energía Atómica, Ciudad Autónoma de Buenos Aires, Argentina.

4 Eng., División Recubrimientos y Tribología. Gerencia de Materiales, GAEN, Comisión Nacional de Energía Atómica, Ciudad Autónoma de Buenos Aires, Argentina.

5 Ph.D. Eng., División Recubrimientos y Tribología, Gerencia de Materiales, GAEN, Comisión Nacional de Energía Atómica, Ciudad Autónoma de Buenos Aires, Argentina.

* Technical contribution to the $1^{\text {st }}$ Workshop on surface treatments of corrosion resistant alloys, July $21^{\text {st }}-25^{\text {th }}$, 2014, São Paulo, SP, Brazil. 


\section{INTRODUCTION}

In aqueous conditions in presence of ions $\mathrm{CO}^{3-}, \mathrm{Cl}^{-}, \mathrm{SO}^{4}=$ and particles harder than the surface, metal parts suffer rapid deterioration, which can be mitigated by employing stainless steel or potentiostatic protection. However, certain ions under high velocities flux added with harder impacting particles promote the breaking down of the protective layer.

Stainless steels and corrosion inhibitors allow reducing the mass loss associated with the pure corrosion effect, allowing erosion loss to be the principal component of wear, although upon increasing the velocity and the turbulence, their protective capacity is diminished. Alternatively, ceramic coatings have been used because their high toughness and good adhesion can protect the surface against erosion, and their chemical inertness protects against corrosion [1].

In general, erosion-corrosion (EC) studies reveal that the increase in the loss of material due to EC is greater than the sum of pure erosion and pure corrosion, which verifies the existence of a combined action [2-5]. It has also been found that for some metallic materials, the passivation zone promotes a decrease in the erosion rate, i.e. passive films generate some protection against erosive particles.

Stack et al. [3] suggest that under EC wear, wear rates are limited to four stages: corrosion stage 1 , corrosion stage 2 , increased wear by pure corrosion, and pure erosion. In the last stage, the effect is due to an increase in temperature and erosion velocity. For tests in which the mass loss is measured gravimetrically, corrosion stage 1 , is characterized by mass loss associated with the dissolution or degradation of the natural protective $\mathrm{Cr}_{2} \mathrm{O}_{3}$ oxide; corrosion stage 2 , shows a mass gain due to the formation of new oxides; in the increased wear by pure corrosion and pure erosion stages, the mass losses are more pronounced, due to the convective and diffusive flow action and the kinetic energy of the particles impinging on the surface, causing the generation of subsurface cracks.

In order to decrease the mass loss rate due stages 3 and 4 , the deposition of ceramic coatings has been proposed as an alternative because of their high hardness, and their chemical and thermal inertia, which generate lower mass loss rates $[1,5-6]$.

With the PVD techniques, there has been success in obtaining coatings at low temperatures (below $400^{\circ} \mathrm{C}$ ), high deposition rates, and the possibility to deposit multilayers or super-networks that exhibit better performance due to the combination of the properties of their components and the laminated structure [7-9]. Indeed, with the diversity of techniques that have emerged for the deposition of hard films, currently there are EC wear studies being carried out on various nitrides and carbides of transition elements, as well as on micro and nanometric multilayers of these, in order to propose better alternatives for the mitigation of the wear of metal parts $[5,6,10-12]$.

\section{MATERIALS AND METHODS}

The experimental procedure used could be divided into two steps: the first one could be characterized with the goal to obtain a coating on a substrate and the second was the study of the coating performance under EC experiments.

The first step could be described as follows: Analysis of the composition of the steel used, heat treatment of the steel, microstructure analysis, measurement of the

* Technical contribution to the $1^{\text {st }}$ Workshop on surface treatments of corrosion resistant alloys, July $21^{\text {st }}-25^{\text {th }}$, 2014, São Paulo, SP, Brazil. 


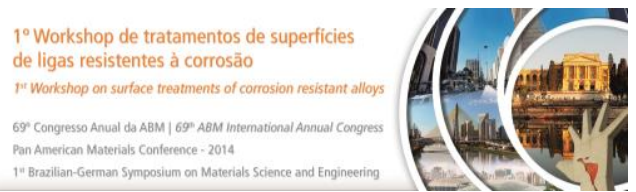

microhardness, coating deposition and coating characterization. The details of this first step will be presented below.

\subsection{Heat Treatment of AISI 440C Steel}

Samples of AISI 440C (see composition in Table 1) of $12.7 \mathrm{~mm}$ in diameter and $5 \mathrm{~mm}$ in thickness were subjected to cryo-quenching and tempering treatments (Figure 1) in the Coatings and Tribology Laboratory (DRyT) of CNEA, to improve hardness and wear resistance. A cryo-quenching process was employed in order to reduce the retained austenite, which is metastable at room temperature and could transform to new martensite during quenching after coating, resulting in volume change, which generates internal stresses, and consequently unacceptable dimensional changes and delayed cracking [13-16].

Table 1. Elemental composition $440 \mathrm{C}$ steel

\begin{tabular}{|c|c|c|c|c|c|c|c|c|c|c|}
\hline Element & $\mathbf{C}$ & $\mathbf{C r}$ & $\mathbf{M o}$ & $\mathbf{S i}$ & $\mathbf{M n}$ & $\mathbf{P}$ & $\mathbf{S}$ & $\mathbf{N i}$ & $\mathbf{C u}$ & $\mathbf{C o}$ \\
\hline \% weight & 1.04 & 16.4 & 0.45 & 0.41 & 0.41 & 0.022 & 0.002 & 0.28 & 0.05 & 0.01 \\
\hline
\end{tabular}

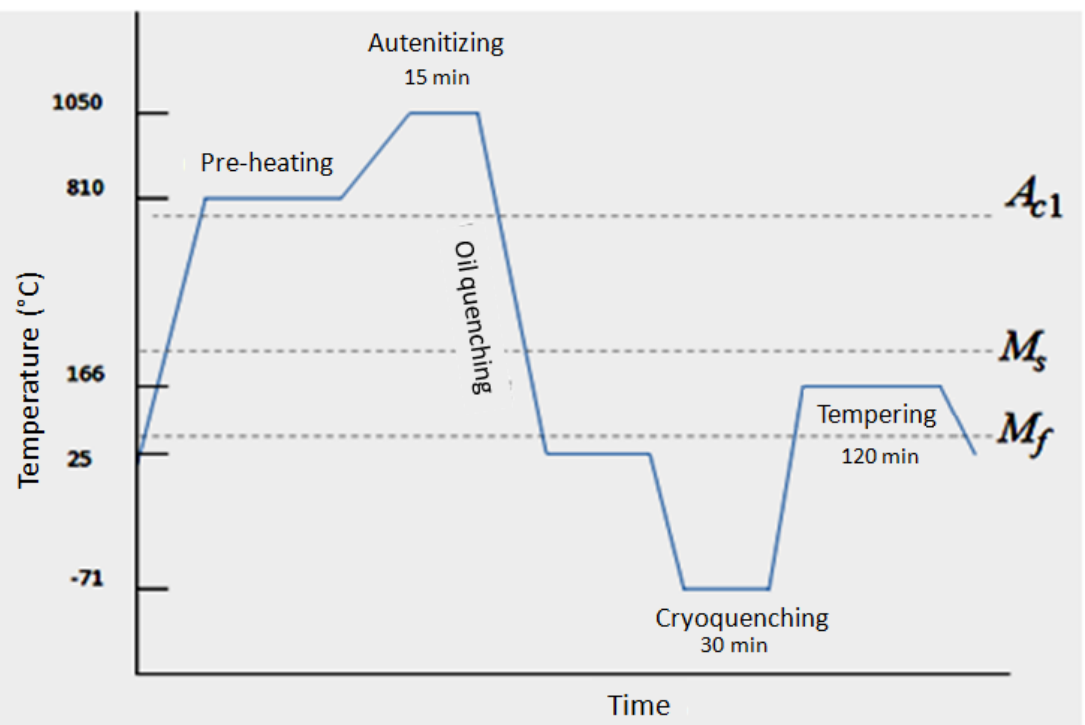

Figure 1. Heat Treatment of AISI $440 \mathrm{C}$ steel. Ac1: initiation of austenite transformation temperature, $M_{s}$ : initiation of martensitic transformation temperature start, $\mathrm{M}_{\mathrm{f}}$ : end of martensitic transformation temperature.

The samples were polished with abrasive paper from 80-800 mesh size. Some of the samples were used for the deposition of coatings and other bare samples were used as a reference for erosion-corrosion tests.

After coating deposition the substrate hardness increased from $(679 \pm 71) \mathrm{HV}_{0.025}$ to (717 \pm 40$) \mathrm{HV}_{0.025}$ due to second precipitation.

\subsection{Coating Deposition}

Two bilayers of $\mathrm{Cr} / \mathrm{CrN}$ were deposited with cathodic arc equipment Nissin Electric CO, LTD RMP-R3-J, Figure 2, in the DRyT - CNEA.

For the deposition of the coatings, the vacuum back-pressure was $3 \times 10^{-5}$ Torr $\left(4 \times 10^{-3} \mathrm{~Pa}\right)$ using a two-stage rotative mechanical pump for the rough vacuum, coupled with a diffusion pump. The target-substrate working distance was $15 \mathrm{~cm}$. The ionic cleaning was made with $\mathrm{V}_{\text {bias: }}-800 \mathrm{~V}$ with $\mathrm{Ar}$ gas for $15 \mathrm{~min}$. Then, the

* Technical contribution to the $1^{\text {st }}$ Workshop on surface treatments of corrosion resistant alloys, July $21^{\text {st }}-25^{\text {th }}, 2014$, São Paulo, SP, Brazil. 
deposition of two bilayers of $\mathrm{Cr}+\mathrm{CrN}$, each layer under $\mathrm{V}_{\text {bias: }}$ - $400 \mathrm{~V}$ for 1.5 min with a flow rate of $40 \mathrm{~cm}^{3}$ of $\mathrm{Ar}$ gas in the Cr layer deposition and $\mathrm{V}_{\text {bias: }}-125 \mathrm{~V}$ for $15 \mathrm{~min}$ with a mixture of $\mathrm{N}_{2}\left(36 \mathrm{~cm}^{3}\right)$ and $\operatorname{Ar}\left(2 \mathrm{~cm}^{3}\right)$ gases in the $\mathrm{CrN}$ layer deposition, was carried out. Between the two bilayers, the voltage sources were turned off without breaking the vacuum.

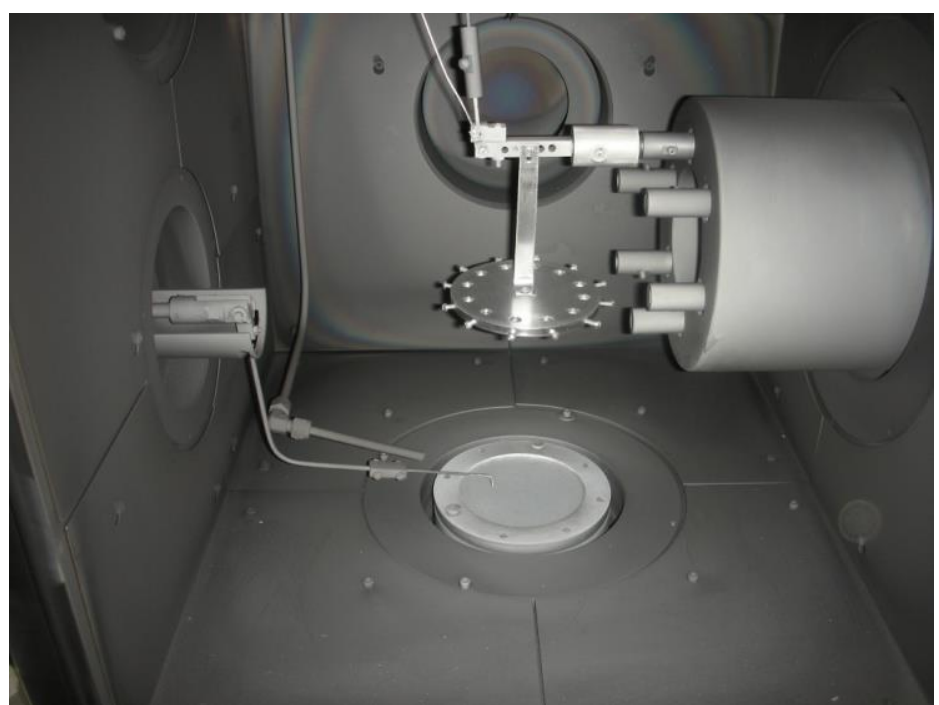

Figure 2. Cathodic-arc PVD deposition chamber.

\subsection{Corrosion and Erosion Test}

The scheme of the test cell of EC by jet impingement is shown in Figure 3 . The cell holds $5 \mathrm{~L}$ of solution, and is self-powered by means of a peristaltic pump, which supplies a constant flow. The nozzle is made of Nylon and has an outlet diameter of $2 \mathrm{~mm}$, at $90^{\circ}$ from the sample.

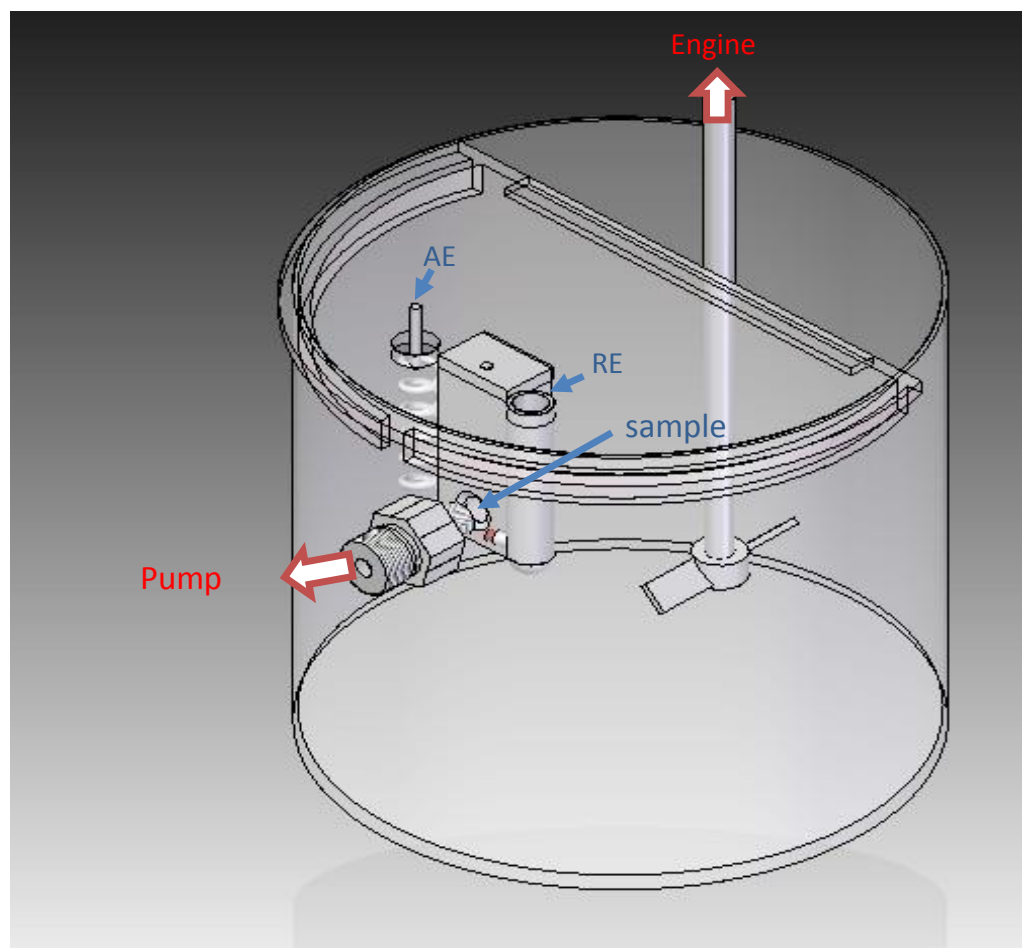

Figure 3. Jet impingement cell for erosion-corrosion test.

* Technical contribution to the $1^{\text {st }}$ Workshop on surface treatments of corrosion resistant alloys, July $21^{\text {st }}-25^{\text {th }}, 2014$, São Paulo, SP, Brazil. 
The cell was coupled to a potentiostat Gamry 600 to generate potentiodynamic polarization curves in order to evaluate the corrosion rate. The reference electrode (RE) of saturated calomel (SCE) was put into a glass shell with a Vycor tip, which acts as a membrane and facilitates the electrochemical measurements without any contamination of the electrode. The auxiliary electrode (AE) of platinum was located near the working electrode (sample), to reduce the ohmic drop during the measurement.

Potentiodynamic curves were initiated once the open circuit potential (OCP) was stabilized. The exposure area of the sample was $78.54 \mathrm{~mm}^{2}$. A sweep was carried out from -0.6 to $0.6 \mathrm{~V}$ vs SCE using a scan rate of $1 \mathrm{mV} / \mathrm{s}$. In all the tests, the samples were immersed for $30 \mathrm{~min}$ in the solution or in the slurry under the action of the jet. The electrochemical parameters were calculated with Tafel extrapolation using E-Chem Analysis-Gamry software.

The corrosion tests were performed in a $3.5 \%$ wt. $\mathrm{NaCl}$ solution, while in the erosion and EC tests slurry composed of a solution with $10 \%$ wt. of silica particles of $0.300-$ $0.212 \mathrm{~mm}$ (AFS 50/70) size was used. In the erosion test, a cathodic voltage of $-1 \mathrm{~V}$ vs $\mathrm{E}_{\text {corr }}$ was supplied in order to avoid mass loss associated with corrosion. In the slurry tests, a paddle stirrer was used in order to facilitate the suspension of the silica particles and supply a homogeneous solution to the pump.

The jet impingement velocities were 4 and $8 \mathrm{~m} / \mathrm{s}$. The test was performed at room temperature $\left(25-28^{\circ} \mathrm{C}\right)$. The Nylon sample holder was of the Avesta cell type in order to avoid crevice corrosion. The sample was placed $5 \mathrm{~mm}$ from the nozzle. The mass loss erosion and EC test were calculated gravimetrically.

The nomenclature used in the samples was as follows:

\begin{tabular}{|c|l|c|}
\hline Material type & \multicolumn{1}{|c|}{ Test type } & Impact velocity \\
\hline a: 440 C steel & $\begin{array}{l}\text { TML: Total material loss by } \\
\text { erosion-corrosion } \\
\text { Wo: pure erosion } \\
\text { Co: } \text { Cr/CrN Bilayer coating }\end{array}$ & $\begin{array}{l}\text { Cw: electrochemical corrosion } \\
\text { rate during the erosion - } \\
\text { corrosion test }\end{array}$ \\
\hline
\end{tabular}

\section{RESULTS AND DISCUSSION}

The characterization of the substrates, the coating and the electrochemical measurements of mass loss of the coated and uncoated samples after completing the tests, as well micrographs will be reported.

\subsection{Characterization of Substrates}

For verification of the phases, the test samples were grinding until 2000 grit SiC sandpaper, polished with $3 \mu \mathrm{m}$ diamond paste and ultrasonic cleaning. The microstructures were revealed by means of different chemical attacks. Figure 4 shows the presence of a very fine martensitic matrix consistent with that exhibited by $440 \mathrm{C}$ steel thermal treated [16]. The existence of a martensitic matrix was checked by measuring the microhardness, by means of a microdurometer Akashi MVK-H2 with certified calibration, which gave a result of $(679 \pm 71) \mathrm{HV}_{0.025}$.

In the micrograph of Figure $2 a$, the steel was etched with Villela solution [17], grain boundaries of the primary austenite were identified. Figure $4 \mathrm{~b}$ shows the micrograph

* Technical contribution to the $1^{\text {st }}$ Workshop on surface treatments of corrosion resistant alloys, July $21^{\text {st }}-25^{\text {th }}, 2014$, São Paulo, SP, Brazil. 


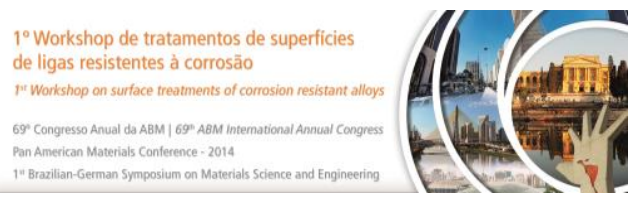

obtained with the Beraha attack [17] and exhibits a dark matrix corresponding to the martensite phase and bimodal size distribution of white areas, which correspond to carbides.
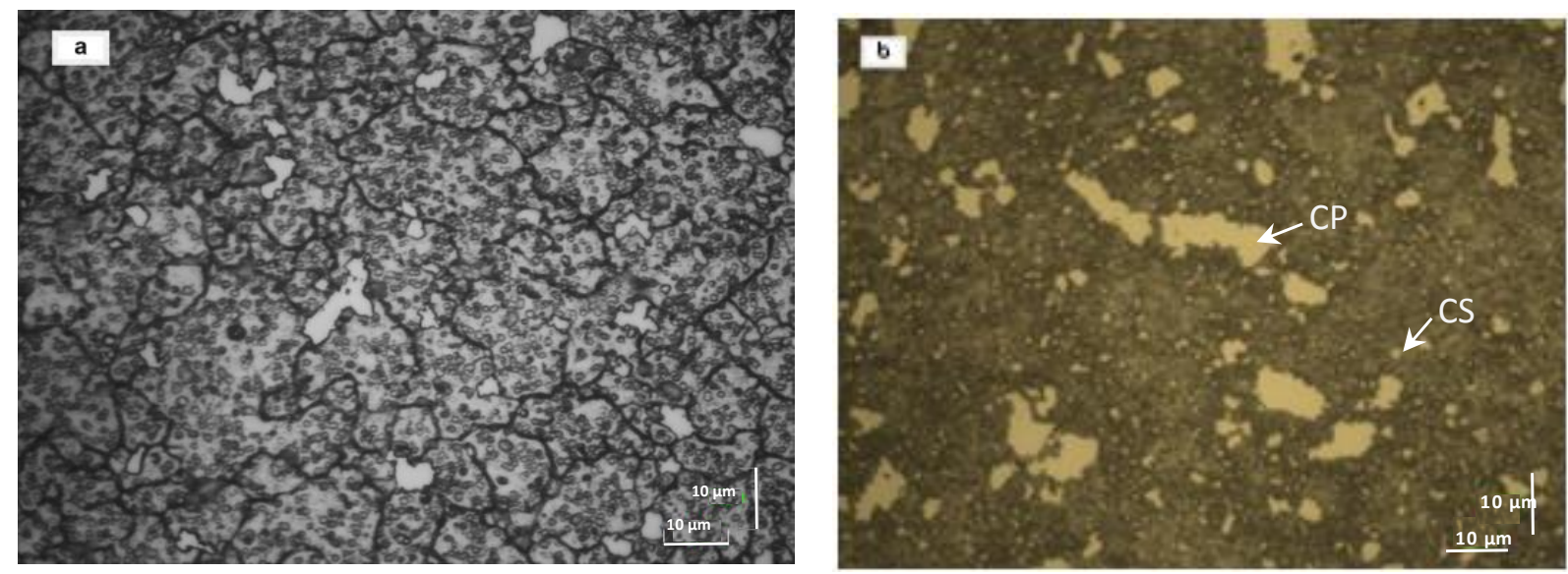

Figure 4. Bright field micrographs. CP: primary carbides, CS: secondary carbides. Etched with a) Villela, b) Beraha.

Quantification of the percentage of carbides was performed following the procedure described in ASTM E-1245 [18], using the Nikon NIS-Elements software through the use of 9 fields with more than 1000 quantified elements. The carbides percentage corresponds to $9.85 \pm 0.02 \%$.

\subsection{Coating Characterization}

The evaluation of the properties of the coating was performed on a standard sample for each batch of coatings, using the equipment of the CTL-CNEA.

The hardness measurement was $(1300 \pm 80) \mathrm{HV}_{0.025}$. Figure 5 shows a micrograph of thickness coating measured with CaloTest equipment CSEM S/N 03-134. The partial and full thickness measured was 3,2 $\mu \mathrm{m}$ and 6,6 $\mu \mathrm{m}$ respectively

* Technical contribution to the $1^{\text {st }}$ Workshop on surface treatments of corrosion resistant alloys, July $21^{\text {st }}-25^{\text {th }}, 2014$, São Paulo, SP, Brazil. 


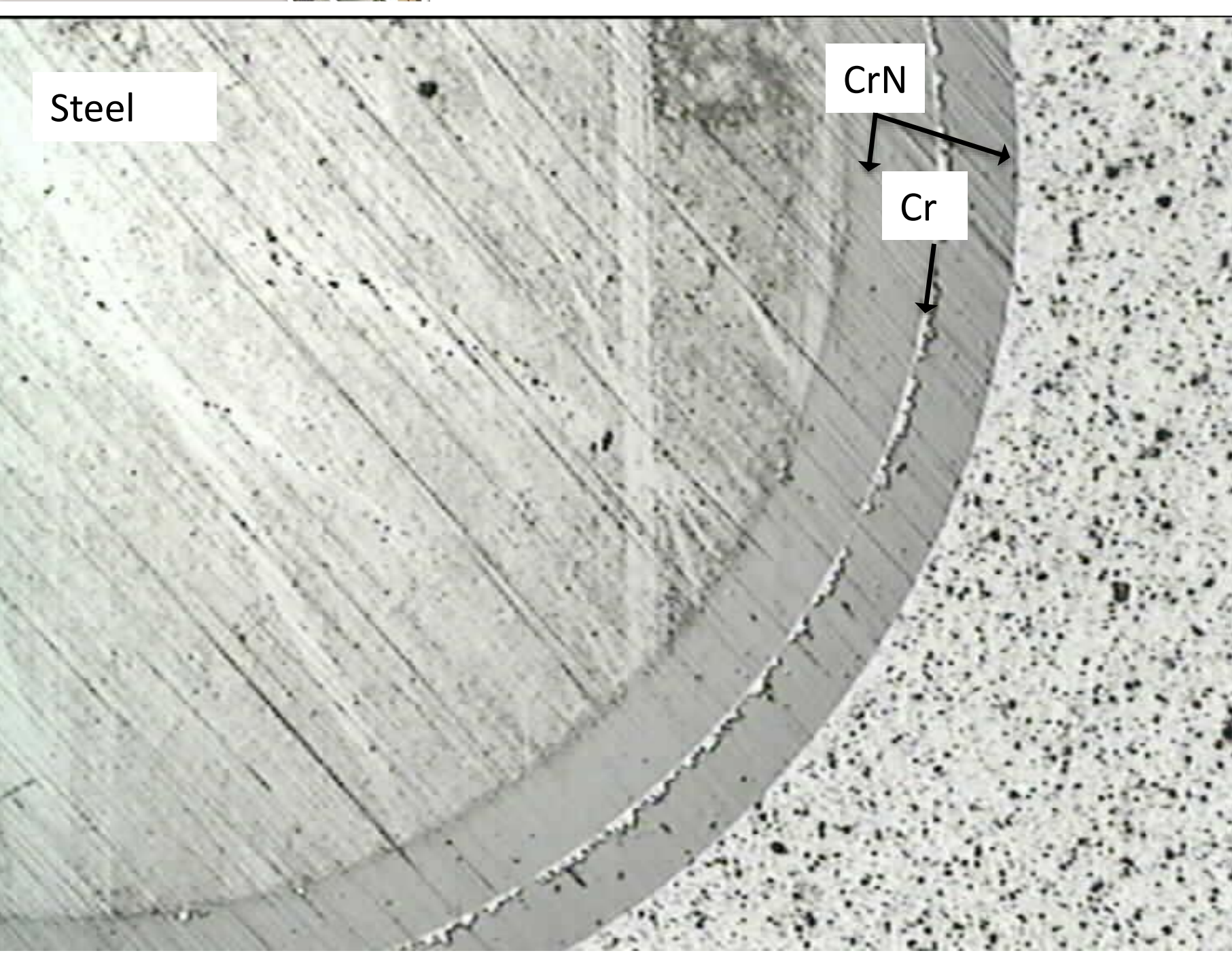

Figure 5. Optical micrograph at 50X of ball crater thickness test for $\mathrm{Cr} / \mathrm{CrN}$ bilayer coating.

The scratch test was performed with CSEM Scratch-Tester S-N 26-393 equipment with a diamond type $C$ Rockwell indenter. The indenter was moved at a speed of 10 $\mathrm{mm} / \mathrm{min}$, linearly varying the load from 0 to $60 \mathrm{~N}$ with a table speed of $100 \mathrm{~N} / \mathrm{mm}$. The critical load was determined by optical microscope, and lineal relation of load vs. table speed was LC 1 : $(38 \pm 10) \mathrm{N}$.

To identify the phases present and their preferred orientation, diffraction measurements were performed on an X-ray diffractometer X'pert Panalytical with $\mathrm{Cu}$ Ka radiation.

The diffraction pattern, Figure 6, shows the presence of a CrN phase (JCPDF00-0110065). It can be noticed that the film has a strong texture at $\mathrm{CrN}$ [220] orientation. This is consistent with the information presented by Grant [19], Oden [20] and Ahn [21] for the combination of parameters used in the deposition of this coating, since the texture of the films is affected by the $V_{\text {bias }}$ and nitrogen partial pressure used in the deposition process [20-23]. The Cr peaks are shift to the left indicating that the crystalline structure has compression microstresses. Microstresses alter the lattice spacing and broadening the diffraction peak [24]. It does not present evidence of $\mathrm{Cr}$ peaks.

* Technical contribution to the $1^{\text {st }}$ Workshop on surface treatments of corrosion resistant alloys, July $21^{\text {st }}-25^{\text {th }}, 2014$, São Paulo, SP, Brazil. 


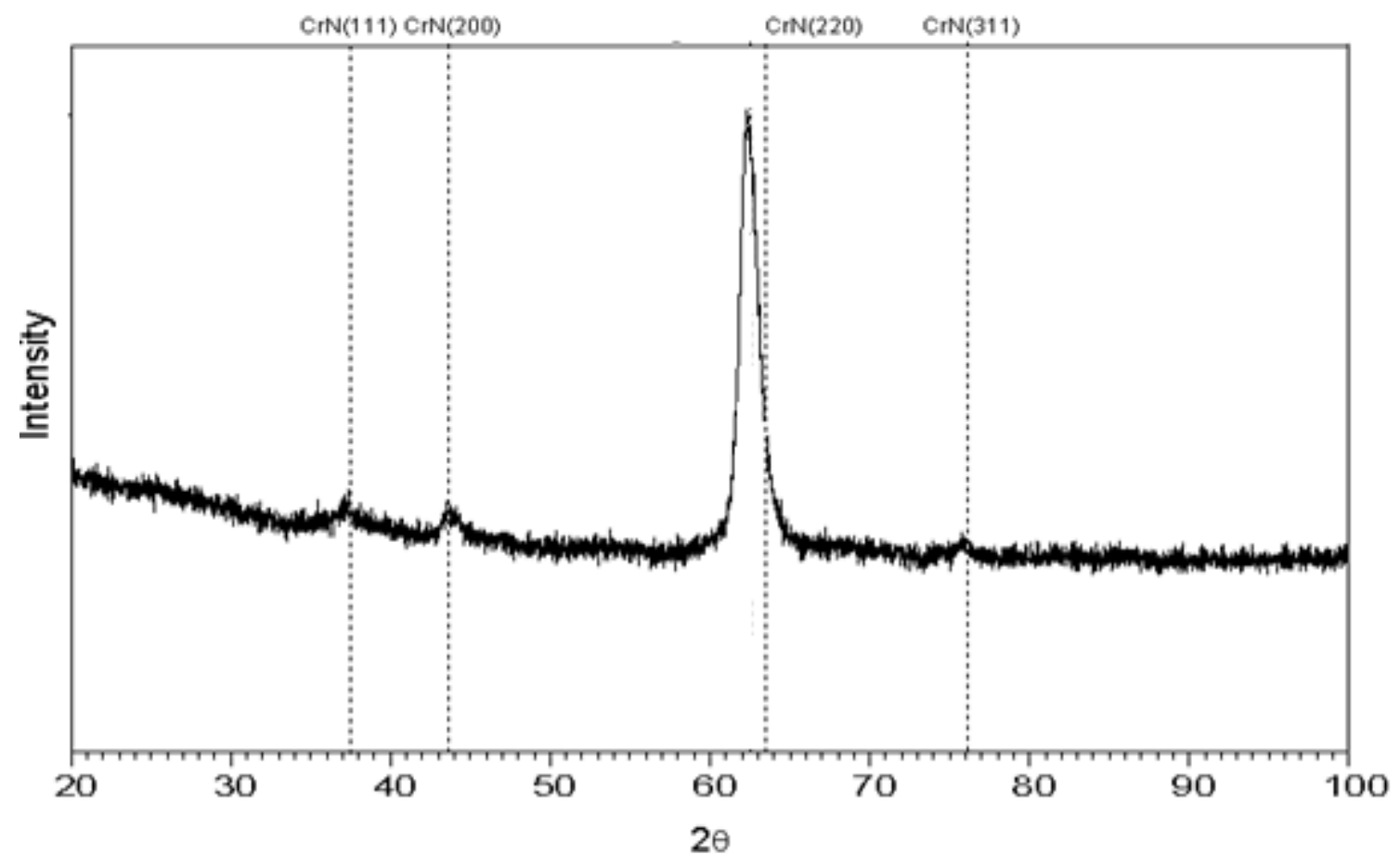

Figure 6. Diffractogram of $\mathrm{Cr} / \mathrm{CrN}$ coating on AISI $440 \mathrm{C}$ steel.

Figure 7a shows the surface microstructure of the coating, in which some surface defects like pinholes and droplets, characteristic of process deposition, are seen. The micrographs were perfomed with SEM JEOL JSM 5910 LV at UNal laboratories.

Figure $7 \mathrm{~b}$ is a transversal micrograph of the coating, and it was obtained by previously fracturing a sample immersed in liquid nitrogen and etching the multilayer coating with a solution of $\mathrm{HNO}_{3}$ and $\mathrm{HF}$ in the ratio $1: 9$ for 30 min. This preferentially attacks the $\mathrm{Cr}$, and so can display the stratification layers.
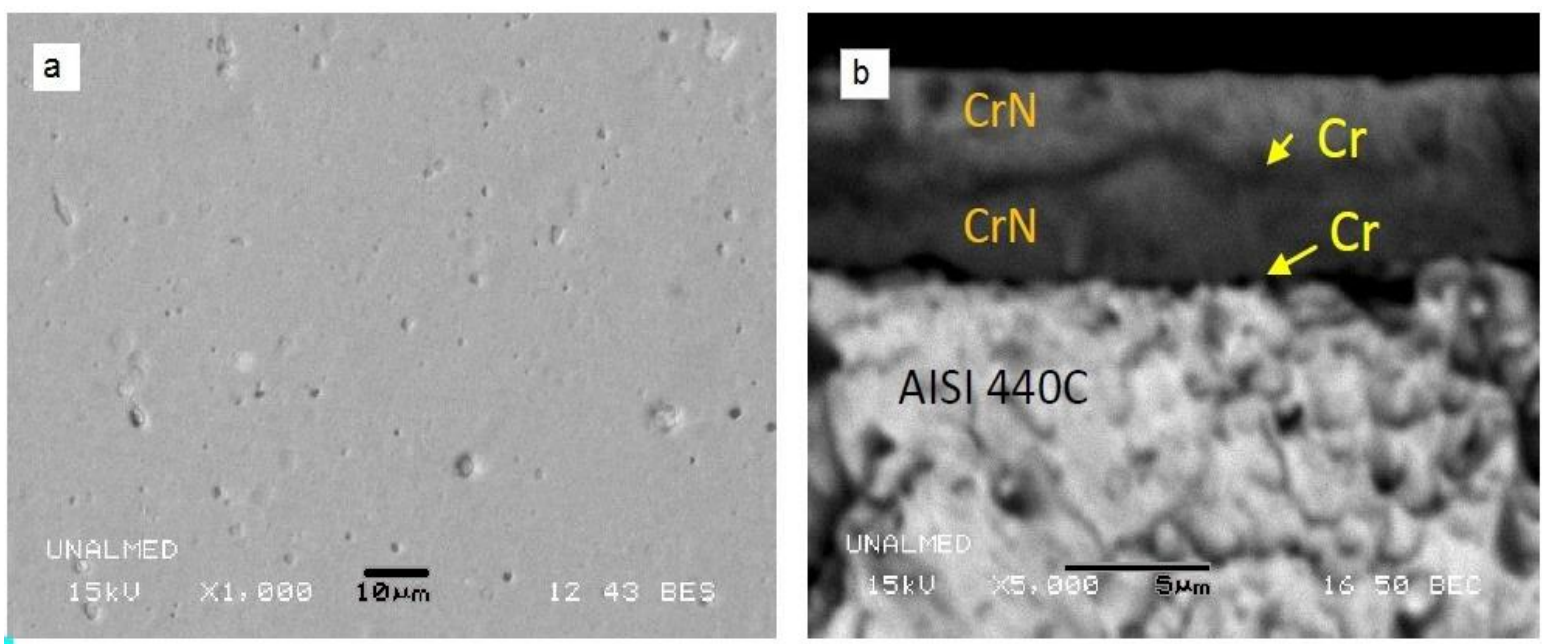

Figure 7. SEM micrographs of $\mathrm{Cr} / \mathrm{CrN}$ coating. a) Surface. b) Transversal.

\subsection{Electrochemical Measurements}

Figure 8 shows the OCP measurements on $440 \mathrm{C}$ surface under the most severe conditions, that is to say, under corrosion and EC with jet velocity of $8 \mathrm{~m} / \mathrm{s}$.

* Technical contribution to the $1^{\text {st }}$ Workshop on surface treatments of corrosion resistant alloys, July $21^{\text {st }}-25^{\text {th }}, 2014$, São Paulo, SP, Brazil. 


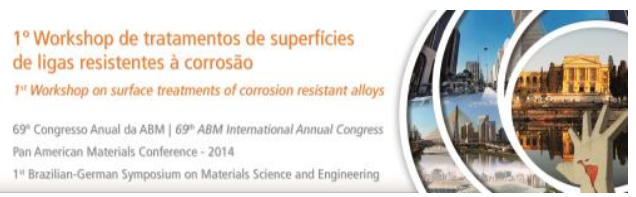

As it can be seen in Figure 8, the agitation does not generate noise in the electrochemical measurements, since at $3600 \mathrm{~s}$, the OCP varies no more than 200 $\mathrm{mV}$.

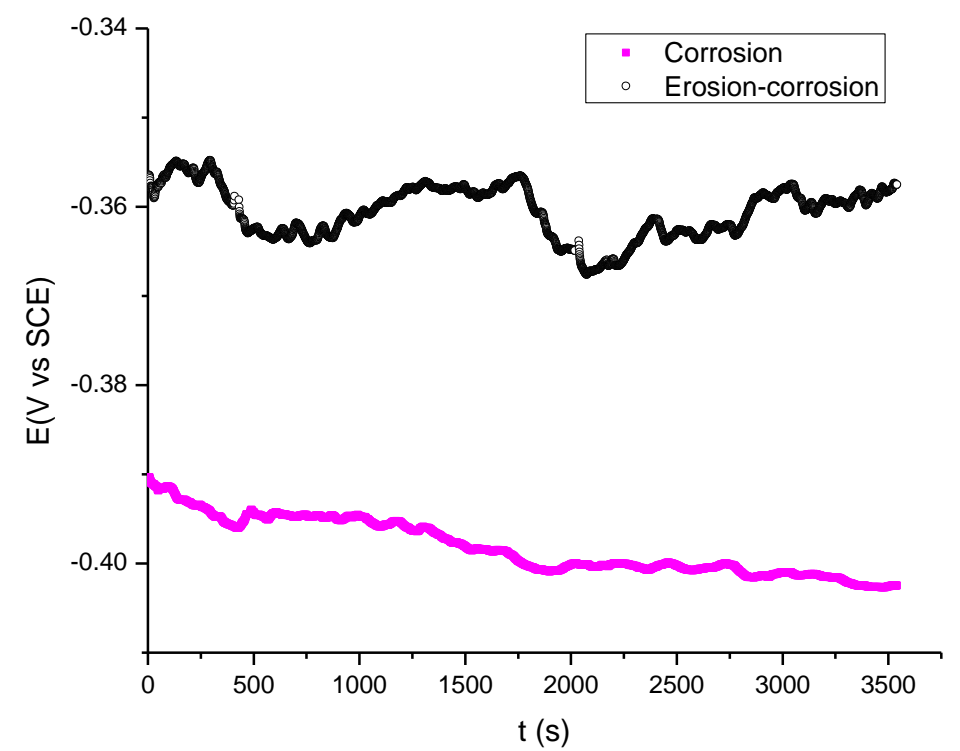

Figure 8. Open Circuit Potencial for pure corrosion and EC to $8 \mathrm{~m} / \mathrm{s}$.

The polarization curves for pure corrosion $\left(\mathrm{C}_{0}\right)$ and erosion-corrosion $\left(\mathrm{C}_{\mathrm{w}}\right)$ carried out on $440 \mathrm{C}$ steel and on a $\mathrm{Cr} / \mathrm{CrN}$ bilayer coating in function of the impact velocity are shown in Figure 9.

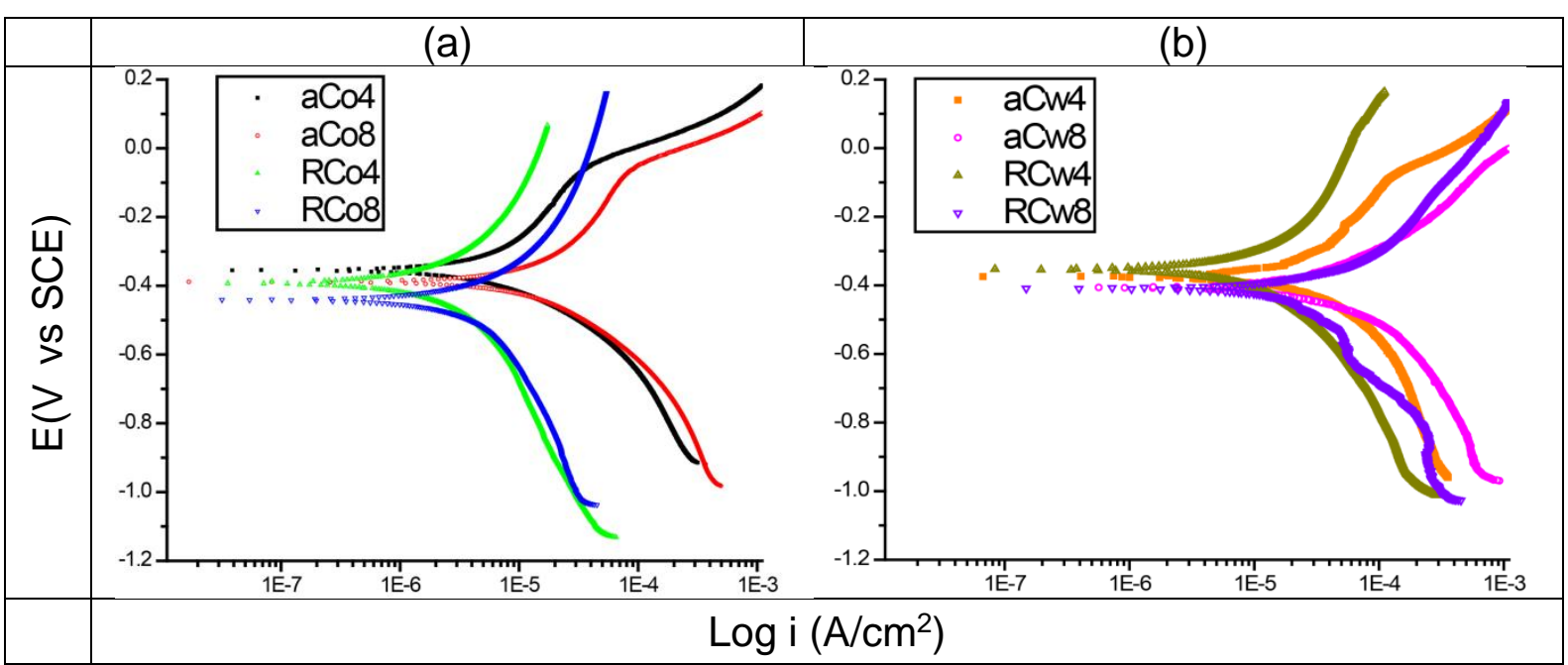

Figure 9 Potentiodynamic polarization curves made at different velocities on the $440 \mathrm{C}$ steel and the coating of $\mathrm{Cr} / \mathrm{CrN}$ in a) pure corrosion b) erosion-corrosion.

For all conditions of wear, the velocity increase causes a higher corrosion current density. The coating protects the surface under conditions of pure corrosion as well as EC; however the corrosion potential is very close to that of the steel, which can be attributed to the porosity of the coating.

* Technical contribution to the $1^{\text {st }}$ Workshop on surface treatments of corrosion resistant alloys, July $21^{\text {st }}-25^{\text {th }}$, 2014, São Paulo, SP, Brazil. 


\subsection{Mass Losses}

Figure 10 shows that the mass losses for pure erosion and erosion-corrosion for the AISI $440 \mathrm{C}$ steel and the $\mathrm{Cr} / \mathrm{CrN}$ bilayer coating. Generally, increasing the velocity produces a higher mass loss rate, which is in accordance with the theories of erosion.

In Figure 10, it can be appreciated that there is greater loss of mass for both materials in erosion-corrosion conditions, the case of martensitic stainless steel being more drastic. Table 2 shows the individual contributions of erosion, corrosion and synergism for each of the evaluated conditions obtained, following the procedure described in ASTM G-119-09 [2].

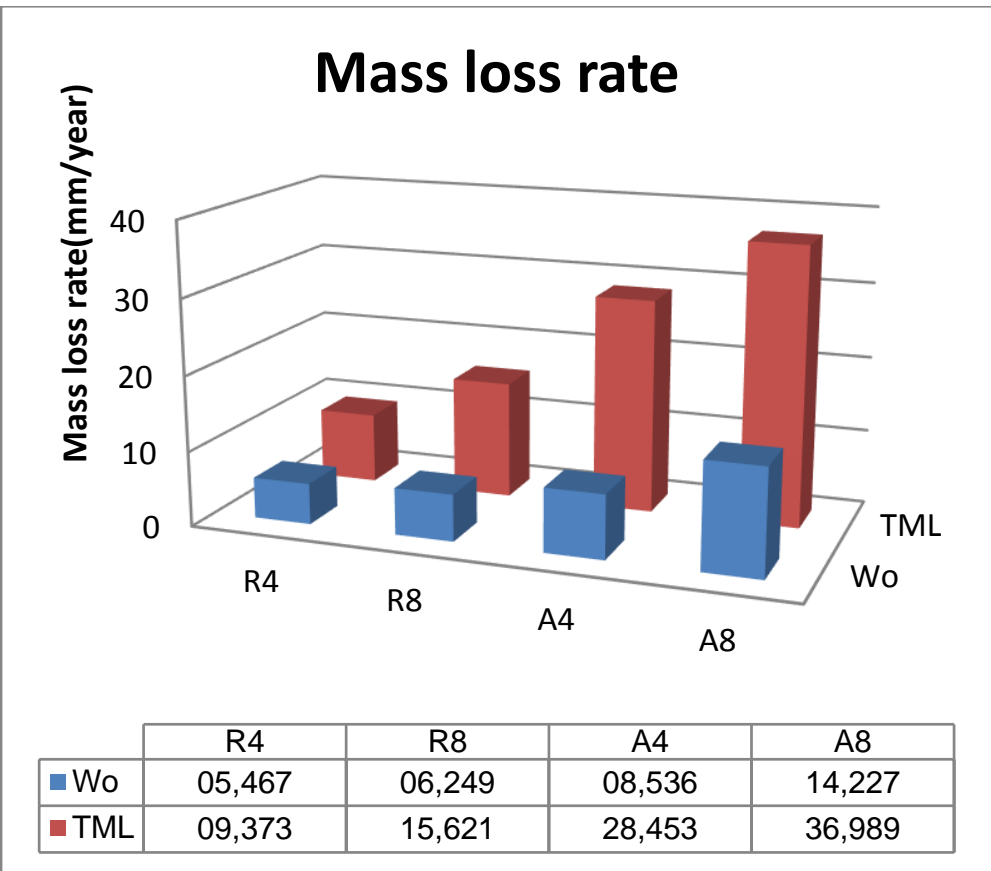

Figure 10. Mass loss rates for $440 \mathrm{C}$ steel and $\mathrm{Cr} / \mathrm{CrN}$ bilayer coating in erosion and $\mathrm{EC}$ at 4 and $8 \mathrm{~m} / \mathrm{s}$.

Table 1. Mass loss rate in EC test. TML: Total material loss rate; $W_{0}$ : mechanical wear rate; $C_{0}$ : electrochemical corrosion rate; $\mathrm{C}_{\mathrm{w}}$ : electrochemical corrosion rate during the corrosive wear process; S: Synernism; $\Delta \mathrm{W}_{\mathrm{c}}$ : Synergistic effect; $\Delta \mathrm{C}_{\mathrm{w}}$ : Additive effect

\begin{tabular}{|c|c|c|c|c|c|c|c|c|c|}
\hline \multirow{2}{*}{\multicolumn{2}{|c|}{$\begin{array}{c}\text { Sample material } \\
\text { Impact velocity }\end{array}$}} & \multicolumn{4}{|c|}{ CrN/Cr coating } & \multicolumn{4}{|c|}{$440 C$} \\
\hline & & \multicolumn{2}{|l|}{4} & \multicolumn{2}{|l|}{8} & \multicolumn{2}{|l|}{4} & \multicolumn{2}{|l|}{8} \\
\hline \multirow{6}{*}{$\begin{array}{l}\text { Mass loss } \\
\text { rate } \\
\text { (mm/year) }\end{array}$} & TML & 9,3728 & & 15,6213 & & 28,4530 & & 36,9889 & \\
\hline & $w_{0}$ & 5,4674 & $58 \%$ & 6,2485 & $40 \%$ & 8,5359 & $30 \%$ & 14,2265 & $38 \%$ \\
\hline & $\mathrm{C}_{\mathrm{o}}$ & $6,8910 \mathrm{E}-06$ & $0 \%$ & $1,3214 \mathrm{E}-05$ & $0 \%$ & $1,7179 \mathrm{E}-05$ & $0 \%$ & $6,1240 \mathrm{E}-05$ & $0 \%$ \\
\hline & $\mathrm{s}$ & 3,9053 & $42 \%$ & 9,3727 & $60 \%$ & 19,9171 & $70 \%$ & 22,7623 & $62 \%$ \\
\hline & $\Delta \mathrm{Cw}_{\mathrm{w}}$ & $1,3513 \mathrm{E}-05$ & & $1,8903 \mathrm{E}-04$ & & $1,0905 \mathrm{E}-04$ & & $2,0800 \mathrm{E}-04$ & \\
\hline & $\Delta \mathrm{Wc}$ & 3,9053 & & 9,3726 & & 19,9170 & & 22,7621 & \\
\hline \multicolumn{2}{|c|}{ Erosive Material } & \multicolumn{8}{|c|}{$10 \%$ wt Silica sand of AFS $50 / 70$ size in $3,5 \%$ wt of $\mathrm{NaCl}$ solution } \\
\hline
\end{tabular}

The pure corrosion mechanism $\left(\mathrm{C}_{0}\right)$ has little effect on the coating and on stainless steel under any of the test conditions. The pure erosion mechanism ( $\left.\mathrm{W}_{0}\right)$ was the greatest wear mechanism, mass loss being higher for uncoated steel. The protective

* Technical contribution to the $1^{\text {st }}$ Workshop on surface treatments of corrosion resistant alloys, July $21^{\text {st }}-25^{\text {th }}$, 2014, São Paulo, SP, Brazil. 
effect of the coating for pure erosion decreases with increasing impact velocity. Moreover, the synergism effect in erosion-corrosion is remarkable for all other conditions, and even more so for the uncoated samples (TML).

Under the conditions tested and with the values reported in Table 2, the mass loss because of the synergism both for $\mathrm{CrN} / \mathrm{Cr}$ coating as well as for the $440 \mathrm{C}$ steel exceeds $40 \%$ of the total mass loss, which means that the mechanisms of interaction between erosion and corrosion are very important for the wearing down of both materials. For all conditions, the coating had a higher resistance, represented by a mass loss rate of about half compared with that obtained for the bare $440 \mathrm{C}$ steel.

Figure 11 shows the SEM micrographs, which confirm that $\mathrm{Cr} / \mathrm{CrN}$ bilayer coating exposed to pure erosion undergoes less material detachment at low velocity, without any observable EDS peaks from the substrate. Under EC, the material detachment is greater, as evidenced in a large and deep scar area and in the presence of Fe peaks. Moreover, the height of the Fe/Cr peaks is near that typical of bare steel. Debris were observed scattered around the scar coating.

From Figure 11, it can be verified that the fracture toughness and hardness of the coating is critical for erosion resistance, since the coating has a mode of failure by brittle fracture. In Figure $11 \mathrm{~d}$, for high velocity EC it can be observed that there is a degradation of the substrate, which shows plastic deformation with formation of valleys generated by the impact of the particles as observed in soft metals like aluminum. The direction range of valleys comes from the interaction between the particles in the jet due to their high concentration, which generates changes in the trajectories, which is reinforced by the particle size distribution in the jet [25].

For all cases, the synergistic effect $\left(\Delta \mathrm{W}_{c}\right)$ is positive, being of a higher value for bare steel. This situation suggests that the surface does not produce corrosion products that help protect the surface $[2-4,22]$, which is verified in potentiodynamic polarization curves of corrosive flux particles, which are shown in Figure 9. It can be seen that there is no characteristic curve with anodic formation of passive layers. The coating was also unable to produce corrosion products that protect the surface, but the $\Delta \mathrm{W}_{c}$ data are less positive, which provides protection twice that of $440 \mathrm{C}$ stainless steel.

* Technical contribution to the $1^{\text {st }}$ Workshop on surface treatments of corrosion resistant alloys, July $21^{\text {st }}-25^{\text {th }}, 2014$, São Paulo, SP, Brazil. 

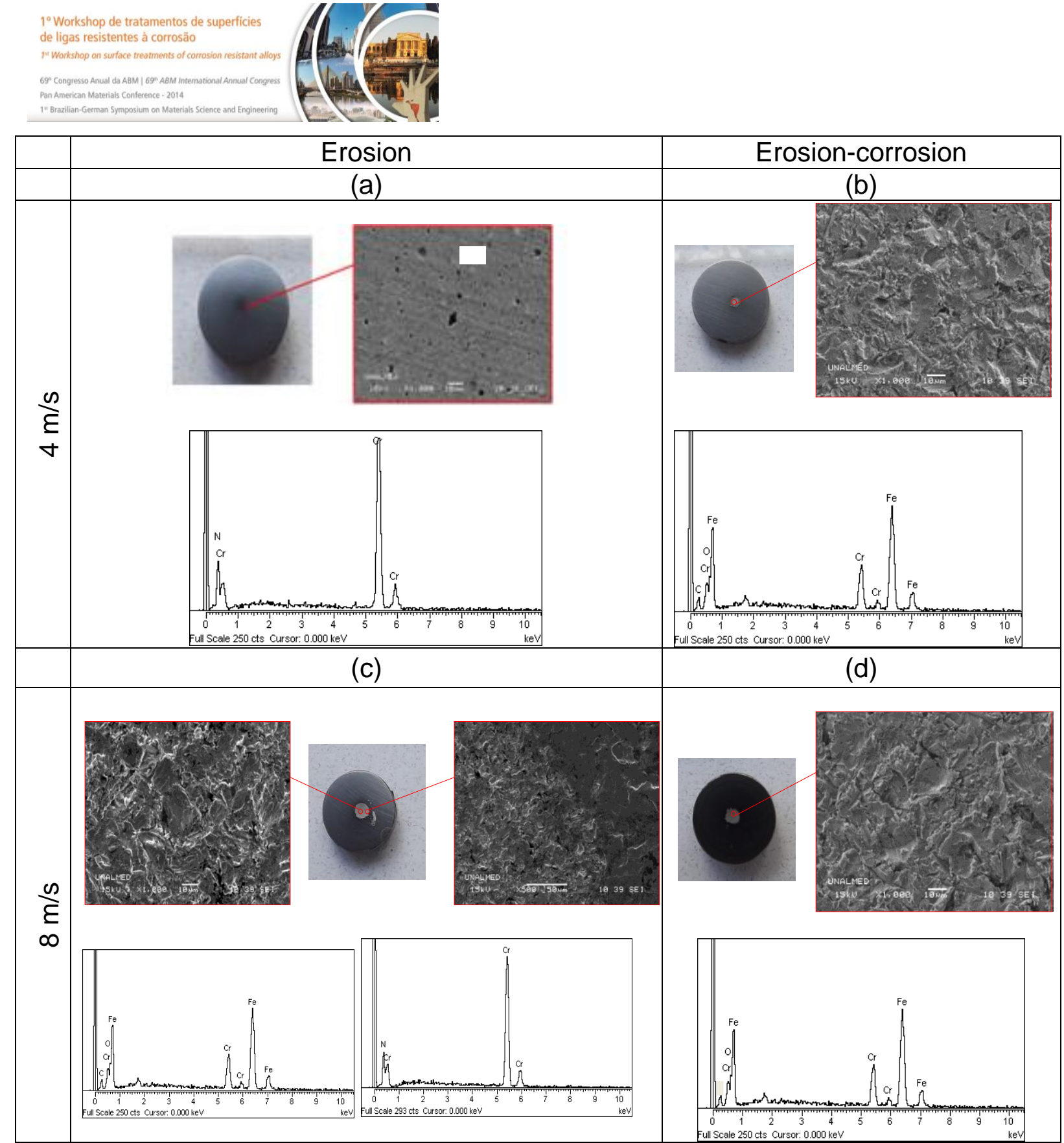

Figure 11 SEM micrographs of coatings after pure erosion and erosion-corrosion tests.

Different authors [5-6,12,26] who have studied some alloys and coatings reported that synergism is an important component of the degradation in EC. Synergism in the case of alloys that undergo passivation is linked to the breakdown of the passive film by the action of the particles, starting the synergic between corrosion and wear of the surface. For the case of multiple layers, as in the case of ceramic coatings, the EC mechanisms and the synergism may be more complex, due to the presence of galvanic between $\mathrm{Cr}$ and $\mathrm{Fe}$.

* Technical contribution to the $1^{\text {st }}$ Workshop on surface treatments of corrosion resistant alloys, July $21^{\text {st }}-25^{\text {th }}$, 2014, São Paulo, SP, Brazil. 


\section{CONCLUSIONS}

The bilayer coating of $\mathrm{Cr} / \mathrm{CrN}$ offered resistance to erosion, corrosion and erosioncorrosion under the impact of 4 to $8 \mathrm{~m} / \mathrm{s}$ compared to the bare surface.

With potentiodynamic polarization curves it was determined that the corrosion potential is very similar to the bare surface, which can be attributed to the electrolyte penetrating the porosity of the coating.

Under the action of jet impact with slurry at $8 \mathrm{~m} / \mathrm{s}$, the coating fractured and detached from substrate. Hence it is recommended that the adhesion of the coating be increased in order to prevent detachment, and also to heat treat the coating after processing in order to achieve a better toughness.

The pure corrosion rate compared to pure erosion is negligible, due to the high solid content (10\% wt.) in the case of erosion, which generates a greater amount of impact, causing greater wear on surfaces through the mechanical effect.

At higher impact velocity, mass loss increased in terms of erosion, flow corrosion and $\mathrm{EC}$ for both materials (440C steel, bare and with coating).

The EC wear for all conditions tested was higher than the sum of the rates of pure erosion and pure corrosion, except for the case of steel subjected to erosion at $4 \mathrm{~m} / \mathrm{s}$. It was verified that the synergism exceeds $40 \%$ of the mass loss for all cases tested, and therefore is an important component of low mass loss under EC wear.

The $440 \mathrm{C}$ steel surface showed a mass loss rate of $304 \%$ under an impact of $4 \mathrm{~m} / \mathrm{s}$ and $237 \%$ under an impact of $8 \mathrm{~m} / \mathrm{s}$ compared with mass loss rates of the coating.

\section{Acknowledgments}

The authors would like to thank Hugo Estupiñan, Ph.D., for his assistance in the electrochemical measurements. We are grateful to the Argentine Atomic Energy Commission (CNEA) and the National University of Colombia (UNal) for the availability of the equipment and the laboratories, at CNEA (Coatings and Tribology Laboratory, metallography, X-ray diffraction) and at UNal (metallography laboratories and testing of materials, advanced microscopy). Thanks go to Dr. Norma Mingolo (CNEA), Mery Arrubla, Martin Griffiths (CNEA) and Manuel Iribarren (CNEA), for their help in conducting the tests, and to COLCIENCIAS and the Directorate of Research, National University of Colombia-Medellín (DIME) for the financial support given through the notice of Opening for Young Researchers No. 510 (2010).

\section{REFERENCES}

1 Mattox DM. Handbook of physical vapor deposition (PVD) processing: film formation Adhesion, Surface Preparation and Contamination Control (Materials Science and Process Technology). USA: Noyes Publication, 1998. 0815514220.

2 ASTM G119-09 "Standard guide for determining synergism between wear and corrosion". ASTM International, West Conshohocken, PA, 2003, DOI: 10.1520/G0119-09, www.astm.org.

3 Stack MM, Lekatos S, Stott FH. Tribology International, Vol 28, pp 445-451, 1995.

4 Stack MM, Zhou S, Newman RC. Wear, Vol 186-187, pp 523-532, 1995.

5 Stack MM, Wang WH. Tribology Letters, Vol 6, pp 23-36, 1999.

6 Stack MM, Wang HW. Wear, Vol 233, pp. 542-551, 1999.

* Technical contribution to the $1^{\text {st }}$ Workshop on surface treatments of corrosion resistant alloys, July $21^{\text {st }}-25^{\text {th }}$, 2014, São Paulo, SP, Brazil. 


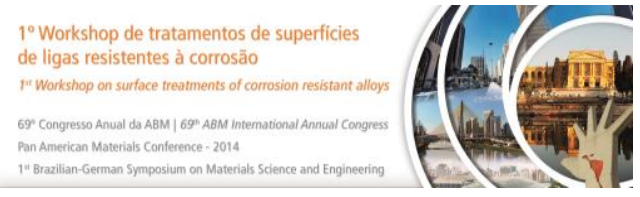

7 Kot M, Rakowski WA, Major $Ł$, Major R, Morgiel J. Surface \& Coatings Technology, Vol 202, pp 3501-3506, 2008

8 Kaciulis S, Mezzi A, Montesperelli G, Lamastra F, Rapone M, Casadei F, Valente T, Gusmano G. Surface \& Coatings Technology, Vol 201, pp 313-319, 2006.

9 Marulanda DM, Olaya JJ, Piratoba U, Mariño A, Camps E. Thin Solid Films, Vol 519, pp 1886-1893, 2011.

10 Perry JM. Erosion-corrosion of WC-Co-Cr cermet coatings. Glasgow: University of Glasgow, 2001.

11 Purandare Y, Stack MM, Hovsepian P. Surface \& Coatings Technology, Vol 201, pp 361-370, 2006.

12 López D, Sanchez C, Toro A. Wear, Vol. 258, pp 684-692, 2005.

13 Barlow L. The effect of austenitising and tempering parameters on the microstructure and hardness of martensitic stainless steel AISI 420. Master Thesis. University of Pretoria. 2009.

14 ASM Handbook. Volume 4. Heat Treatment. USA, 1991. 0871703793,

15 Das D, Dutta AK, Ray KK. Wear, Vol 266, pp 297-309, 2009.

16 Jha AK, Swathi Kiranmayee M, Ramesh Narayanan P, Sreekumar K, Sinha PP. Journal of Materials Engineering and Performance, Vol 21, pp 1076-1084, 2012

17 Vander Voort GF, Manilova EP, Michael JR, Lucas GM. Study of selective etching of carbides in steel. www.dgm.de. Buehler Ltd. Web. 16 Sep 2013. $<$ www.dgm.de/past/2004/metallographie/download/686-60.pdf>

18 ASTM E 1245-03. Standard practice for determining the inclusion or secondphase constituent content of metals by automatic image analysis. ASTM International, West Conshohocken, PA, 2008, DOI: 10.1520/E1245-03R08, www.astm.org.

19 Grant WK, Loomis C, Moore JJ, Olson DL, Mishra B, Perry AJ. Surface and Coatings Technology, Vol 86-87, pp 788-796, 1996.

20 Oden M, Ericsson C, Håkansson G, Ljungcrantz $H$. Surface and coatings technology, Vol 114, 39-51, 1999.

21 Ahn SH, Choi YS, Kim JG, Han JG. Surface and Coatings Technology, Vol 150, pp 319-326, 2002.

22 Chang ZK, Wan XS, Pei ZL, Gong J, Sun C. Surface \& Coatings Technology 205 (2011) 4690-4696.

23 Warcholinski B, Gilewicz A. Tribological properties of CrNx coatings. Journal of achievements in materials and manufacturing engineering. Vol 37. Dec, 2009.

24 Noyan C, Cohen JB. Residual Stresses -Measurement by diffraction and Interpretation", Springer-Verlag, N. Y. 1987, ISBN 0-387-96378-2.

25 Efird KD. Corrosion 2000. NACE International, 2000.

26 López D, Congote JP, Cano JR, Toro A, Tschiptschin AP. Wear, Vol 259, pp 118-12, 2005.

* Technical contribution to the $1^{\text {st }}$ Workshop on surface treatments of corrosion resistant alloys, July $21^{\text {st }}-25^{\text {th }}$, 2014, São Paulo, SP, Brazil. 